\title{
The effect of transglutaminase on colloidal stability of milk proteins
}

\author{
Maria Tarapatskyy $^{1} \cdot$ Jacek Domagała $^{2} \cdot$ Grzegorz Zaguła $^{1} \cdot$ Bogdan Saletnik $^{1} \cdot$ Czesław Puchalski $^{1}$
}

Received: 12 September 2018 / Accepted: 2 May 2019 / Published online: 15 May 2019

(c) The Author(s) 2019

\begin{abstract}
Food industry is on constant search for improved, enzymatically modified forms of proteins, which are the most important functional food ingredients, capable of either introducing or modifying texture, appearance, and flavour. One of the key aspects of food design is creating new functional properties and novel food macro- and microstructures in order to provide tailored food characteristics expected by consumers. Milk proteins are among the most thoroughly studied protein complexes occurring in foods and having a wide range of functionalities. The common usage of milk proteins has also contributed to the development of techniques designed to modify and improve functional properties of milk proteins. The aim of this study was to investigate the impact of enzymatic modification induced by microbial transglutaminase (TGM) in milk proteins on the range of cross-linking as well as heat and ethanol stability of these proteins. Milk used in the study was subjected to

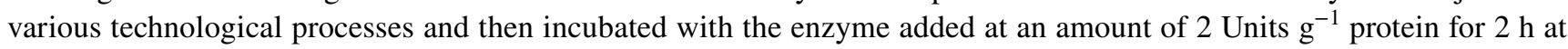
$40{ }^{\circ} \mathrm{C}$. Modification of milk proteins by transglutaminase leads to their partial cross-linking and formation of high molecular weight polymers in the range of 55-200 kDa. The changes of cross-links between milk proteins occur most dynamically in the first hour of incubation at $40{ }^{\circ} \mathrm{C}$. Enzymatic modification of milk proteins significantly increases the ethanol stability of raw as well as pasteurized milk and UF concentrate. Addition of transglutaminase does not change the heat stability of milk measured as the time of heat coagulation at $140^{\circ} \mathrm{C}$.
\end{abstract}

\section{Graphical abstract}

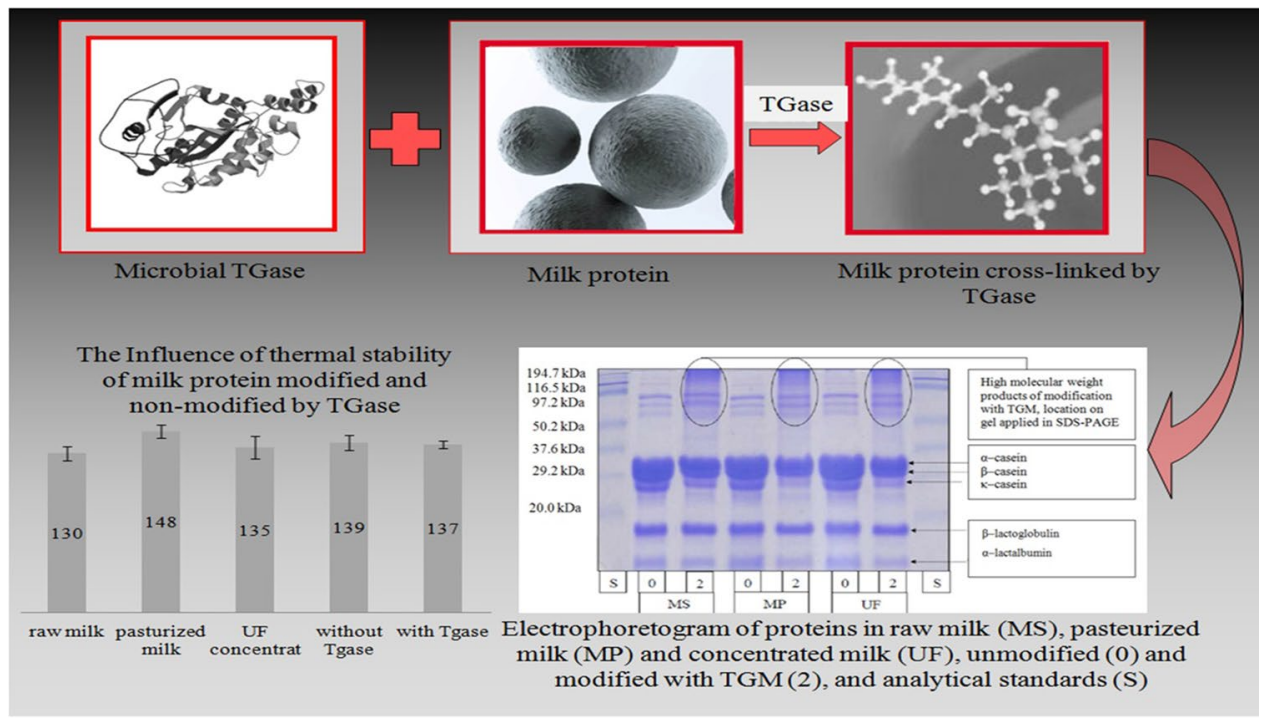

Keywords Milk proteins $\cdot$ Microbial transglutaminase $\cdot$ Heat stability $\cdot$ Ethanol stability

Extended author information available on the last page of the article 


\section{Introduction}

Milk proteins are among the most thoroughly studied protein complexes occurring in foods and having a wide range of functionalities. The complex comprises two classes of proteins differing in terms of their physicochemical properties and the form in which they appear. The first class is made of temperature resistant phosphoproteins, known as caseins, which most frequently take the form of colloidal aggregates called casein micelles. The second class includes whey proteins with globular structure, which undergo thermal denaturation but remain in the solution at the isoelectric point of casein [1].

From the nutritional point of view milk proteins in the diet are a rich source of amino acids and immunity enhancing compounds, as well as biologically available forms of mineral elements, i.e. calcium, phosphorus and magnesium. Suitable fractional composition of milk proteins provides protection for the colloidal system of these proteins, ensuring stability during such technological processes as freezing and heating. Because of their excellent the functional properties, easy availability, as well as low costs of purifying and fractioning, milk proteins have been more and more frequently used as popular functional additives in the form of highly purified commercial preparations based on isolates and concentrates of the specific fractions and their mixtures. The common usage of milk proteins has also contributed to the development of techniques designed to modify and improve functional properties of milk proteins. Such operations increase applicability of milk proteins and make it possible to use by-products of dairy processing [2]. In addition to physical and chemical methods of processing milk proteins there are also enzymatic methods enabling changes in their functional properties.

Transglutaminase (EC 2.3.2.13) is an enzyme catalyzing the formation of cross-links in numerous proteins contained in food, for instance in milk proteins, which results in changing their techno-functional properties. To date, industrial applications of transglutaminase have been related mainly to cross-linking of meat and fish proteins [3]. Modification of proteins contained in milk and assessment of products, including side products, obtained from the modified milk may lead to expanding applicability of dairy products and to developing new options for making use of materials obtained as side-products.

Heat stability of milk relates to its capacity to retain colloidal properties at high temperatures. It depends on the chemical composition, protein contents and proportions of specific fractions, ion and salt concentrations as well as active and potential acidity. Indirectly heat stability depends on the breed of cows, their health status, feeding method and season of the year [4-6]. By heating milk proteins it is possible to alter nutritional value, external appearance, colour, water absorbability, texture and rheological properties of products. The heating process causes numerous changes in the structure and biological activity of milk ingredients [7].

Besides destroying microorganisms, heat treatment of milk induces such changes as inactivation of enzymes, denaturation of whey proteins, altered associations of casein micelles, altered chemistry in chains of amino acids, and changes in the mineral components of milk, which may impact functional properties of milk proteins. Heat stability is mainly impacted by к-casein, which constitutes the outer layer of casein sub-micelles built of the remaining fractions [8].

Thermal denaturation of whey proteins occurs at the temperature exceeding $65-70{ }^{\circ} \mathrm{C}$. The protein most susceptible to heat denaturation is $\beta$-lactoglobulin $(\beta-\mathrm{LG})$, which in course of the process binds to $\kappa$-casein via disulfide bridges; as a result, $\kappa$-casein gains new interfacial surface and acquires new properties [2]. Formation of $\beta-\mathrm{LG} / \kappa-$ casein complex depends on the percent rate of $\kappa$-casein and is important for a number of technological processes, such as aggregation of whey proteins, rennet coagulation, as well as stabilization of UHT milk ingredients [6,9].

Heat stability is important in the process of manufacturing durable dairy products such as powdered milk, baby food, dietary supplements and unsweetened condensed milk, as well as sterilized milk [10].

In the scientific literature from recent years there are works regarding impact of enzymatic modification by transglutaminase on the functional properties of individual protein fractions isolated from milk liquid. Much less information can be found on the modification of proteins in natural raw milk and milk subjected to a variety of treatments, as well as proteins found in various protein dairy preparations and by-products. There are no specific reports on the modification of liquid milk as a complex of proteins and the impact of many physical, chemical and enzymatic factors directly on the mixture of milk proteins in their natural liquid form without separation into selected factions. It is also known that the enzyme tranglutaminase has a weaker effect on whey proteins and is much better crosslinked with casein proteins, which can be noticed during the separation of modified milk protein fractions by SDS-PAGE electrophoresis.

In our study, the main goal was to determine whether casein and whey proteins cross-linked with TGM will remain stable in the colloidal solution which is cow's milk, especially after adding strong dehydrating substances that destabilize the colloidal system, i.e. ethanol [11]. The secondary objective was to indicate the extent of changes in the properties of liquid milk proteins crosslinked by TGM. Taking into consideration the conditions of incubation of 
milk with the enzyme $\left(40{ }^{\circ} \mathrm{C} / 2 \mathrm{~h}\right)$, the results of experiments carried out in this study also inform about the degree of technological usefulness of modified milk as well as its freshness and ionic stability.

The aim of this study was to investigate the positive influence on the heat stability and ethanol stability of milk liquid modified by transglutaminase wich induced enzymatic cross-linking between proteins as well as the evaluate the range of cross-linking. The utilitarian purpose of this work was to formulate recommendations for industrial practice regarding the extent of changes in functional properties of proteins in milk and protein dairy preparations after modification by transglutaminase, and indications of products in which this modification brings the best results.

\section{Materials and methods}

\section{Milk samples}

The study assessed bovine milk originating from a herd of cows representing Polish black and white breed, at a private ecological milk farm in Olszanica near Krakow, regularly supervised by the Regional Veterinary Service. Cows' milk obtained at a morning milking was filtered with the use of gauze in order to remove mechanical contaminants; it was heated to the temperature of $40{ }^{\circ} \mathrm{C}$ and subjected twice to centrifugation process in LWG 24E fat separator from Spomasz, Poland. Afterwards its chemical composition was assayed. The research was carried out in 2016 as part of the project on the search for innovative ways to improve the technological and functional properties of milk proteins.

\section{Conditions of the experiment}

Skimmed milk was divided into three parts. The first part of raw milk was heated to the temperature of $40{ }^{\circ} \mathrm{C}$ and incubated with transglutaminase; the second part of milk was pasteurized at $72{ }^{\circ} \mathrm{C}$ for $15 \mathrm{~s}$, cooled town to $40{ }^{\circ} \mathrm{C}$ and incubated with transglutaminase; the third part was heated to the temperature of $50{ }^{\circ} \mathrm{C}$, condensed by means of ultrafiltration technique with the use of $\mathrm{CH} 2 \mathrm{~A}$ apparatus and Hollow Fiber filter, with $30 \mathrm{kDa}$ pores size, manufactured by Amicon, Switzerland, to obtain twofold condensation degree (v/v), the concentrate was pasteurized at $72{ }^{\circ} \mathrm{C}$ for $15 \mathrm{~s}$, cooled down to $40{ }^{\circ} \mathrm{C}$ and incubated with transglutaminase. Each time, after incubation was completed, the enzyme was inactivated by heating the sample to and retaining it in the temperature of $72{ }^{\circ} \mathrm{C}$ for $60 \mathrm{~s}$, then the sample was cooled down to ambient temperature and subjected to assay process. In order to specify the optimal conditions for enzymatic modification of milk proteins with the use of transglutaminase, initial assessment was carried out to determine the adequate level of transglutaminase to be added to milk, as well as $\mathrm{pH}$ and conditions of incubation with the enzyme. The initial assessment showed the most effective addition of the enzyme was at the level of 2 Units $\mathrm{g}^{-1}$ of protein, and the optimum conditions of incubation with the enzyme were at the temperature of $40^{\circ} \mathrm{C}$ for $2 \mathrm{~h}[12,13]$.

\section{Analytical procedures}

Analyses of raw milk (MS), pasteurized milk (MP) and ultrafiltered milk (UF), both modified (2) and non-modified (0) with TGM, were designed to determine the range of crosslinking in the proteins based on electrophoretic separation on polyacrylamide gel (SDS-PAGE) and measured heat stability and ethanol stability. Separation of protein fractions was carried out with the use of electrophoretic method on SDSPAGE with Mini PROTEAN ${ }^{\circledR} 3$ Cell System from Bio-Rad, following the methodology described by Rossa et al. [14].

\section{Determination of physiochemical properties}

The chemical composition of the prepared products was examined with the use of Milkoscan 1200 apparatus from Foss (Denmark). Measurement of $\mathrm{pH}$ was performed with an electronic $\mathrm{pH}$ Meter from GIB Industries (Germany). Active acidity was determined in compliance with AOAC methodology and protein content was identified with the use of Kjeldahl method [15].

\section{Analysis of milk stability}

Determination of heat stability at $140{ }^{\circ} \mathrm{C}$ was carried out with the use of methodology described by Davies and White [9]. Milk samples of $3 \mathrm{ml}$ volume were measured out to special glass test tubes which were then carefully fixed in metal grips and placed in oil bath. The result was recorded as time (s) of heat coagulation of milk samples at $140^{\circ} \mathrm{C}$. Alcohol number was determined in accordance with the method described by Jurczak [16]. Titration of milk sample was carried out with the use of automatic burette and $96 \%$ ethanol.

\section{Chemicals and reagents}

The experiments were carried out with the use of the enzyme in the form of Activa MP microbiological transglutaminase preparation (TGM) of declared activity 100 Units per $1 \mathrm{~g}$ of the preparation $\left(\mathrm{U} \mathrm{g} \mathrm{g}^{-1}\right)$, from Ajinomoto Foods Europe S.A.S, France. The measurements were performed with the use of analytical purity grade reagents, ethanol from $\mathrm{POCH}$, Poland as well as deionized water obtained from HLP 5P deionizer manufactured by Hydrolab Polska. 


\section{Statistical analysis}

All the analyses were made in three independent replications for each sample. The acquired findings were subjected to statistical analyses with the use of Statistica ver. 10.0. The significant differences between the mean values were obtained by Two-way analysis of variance (ANOVA) followed by Duncan's multiple range test.

\section{Results and discussion}

Composition and physicochemical properties of milk impact its heat stability, coagulation time and the properties of the obtained gel. Findings related to the composition and physicochemical properties of raw milk and UF concentrate used in the part of the study are presented in Table 1.

West et al. [17] specify the average range of dry matter contents in bovine milk at the level of $11-15 \%$. The mean dry matter content in the examined raw milk was slightly lower and amounted to $9.23 \%$, but it was skimmed milk, containing only $0.09 \%$ of fat. An increase in dry matter contents may be achieved by concentration of ingredients via ultrafiltration. This technique is recommended particularly in the technology of manufacturing fermented milk beverages, cheeses and milk proteins concentrates and it facilitates the process of normalizing dry matter ingredients and their respective proportions $[18,19]$. UF concentrate obtained from skimmed milk was found with the contents of dry mass at the level of $12.23 \%$, and with fat content of $0.11 \%$.

Besides fat, protein is the basic ingredient of dry matter in milk. It impacts the effectiveness of cheese production process, texture of gel and nutritional value of milk [20]. It was necessary to determine protein contents in the examined milk in order to define the proper enzyme addition, because this ingredient was the substrate for transglutaminase. Mean protein content in the skimmed milk amounted to $3.36 \%$, and in UF concentrate to $6.3 \%$.

Acidity and $\mathrm{pH}$ of milk is an indicator of its freshness and microbiological status. The examined milk was fresh, and originated from healthy cows, which is expressed by normal values of $\mathrm{pH}$ and titratable acidity.

Varied effects of cross-linking in milk proteins were confirmed by electrophoretic separations on polyacrylamide gel showing the influence of transglutaminase on proteins in raw, pasteurized and concentrated milk. Separation of milk proteins in modified and non-modified milk samples, with the use of SDS-PAGE electrophoresis, is presented in Fig. 1.

There was a significant decrease in the contents of casein monomers, visualized on polyacrylamide gel in the milk samples modified with transglutaminase (Fig. 1, lines 2). The changes occurred most rapidly within the fractions of $\kappa$ - and $\beta$-casein in particular in the samples of pasteurized milk and milk concentrate. This is consistent with the

Table 1 The composition and physical properties of raw skim milk (MS) and concentrated milk (UF) (mean values \pm SD)

\begin{tabular}{|c|c|c|c|c|c|c|c|}
\hline Type of milk & Dry matter $\%$ & Fat $\%$ & Protein $\%$ & Lactose $\%$ & Density $\mathrm{g} \mathrm{ml}^{-1}$ & $\mathrm{pH}$ & $\begin{array}{l}\text { Titratable } \\
\text { acidity } \\
{ }^{\circ} \mathrm{SH}\end{array}$ \\
\hline MS & $9.23 \pm 0.12$ & $0.09 \pm 0.01$ & $3.36 \pm 0.70$ & $5.06 \pm 0.09$ & $1.037 \pm 0.0$ & $6.57 \pm 0.06$ & $6.3 \pm 0.1$ \\
\hline UF & $12.23 \pm 0.21$ & $0.11 \pm 0.05$ & $6.3 \pm 0.11$ & $4.79 \pm 0.08$ & $1.046 \pm 0.0$ & $6.40 \pm 0.06$ & $8.6 \pm 0.6$ \\
\hline
\end{tabular}

Fig. 1 Electrophoretogram of milk proteins cross-linked by TGM; raw milk (MS), pasteurized milk (MP), concentrated milk (UF), unmodified (0), modified TGM (2), analytical standards (S)

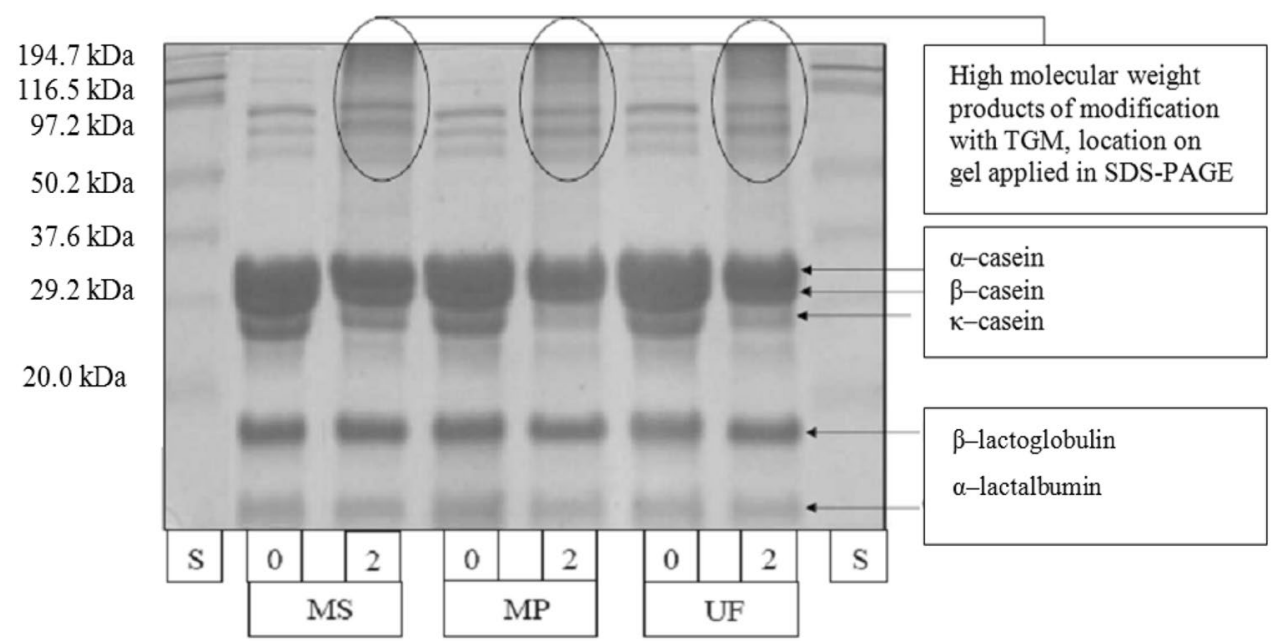


findings reported by Hinz et al. [21] who demonstrated that cross-links are formed more rapidly by $\kappa$ - and $\beta$ - monomers than within $\alpha_{\mathrm{s} 1}$-casein. Electrophoretic separation also suggests that whey proteins participate in establishing crosslinks which is reflected by the decrease in the contents of $\alpha$-lactalbumin fraction. The findings for all the modified milk samples showed that high molecular weight compounds in the range of molecular weights from 55 to $194 \mathrm{kDa}$ were located in the upper part of the polyacrylamide gel. Similar relationship based on SDS-PAGE separations was observed by O'Sullivan et al. [22] and Pinterits and Arntfield [23]. Oligomers were also found in TGM modified samples by Abd-Rabo et al. [24], who applied SDS-PAGE method to examine samples of whole and skim bovine milk. They also demonstrated that contents of milk fat negatively affected the range of cross-linking.

According to Sharma et al. [25] and Moon et al. [26] most cross-links occur during the first $30 \mathrm{~min}$ of incubation with the enzyme at $40{ }^{\circ} \mathrm{C}$.

Lorenzen [27] conducted selective chromatographic separation of reconstituted powder milk samples after 4-h incubation with TGM at $40{ }^{\circ} \mathrm{C}$, and found visible increase in the contents of casein polymers in TGM modified samples with a decreasing number of monomers of specific fractions.

In order to visualize the influence of the duration of milk and enzyme incubation on proteins cross-linking, electrophorectic separation was carried out for the proteins of pasteurized milk, non-modified and incubated with TGM for the duration ranging from $30 \mathrm{~min}$ to $4 \mathrm{~h}$, at $40^{\circ} \mathrm{C}$, with an addition of the enzyme at $2 \mathrm{U} \mathrm{g}^{-1}$ of protein. The obtained separations are presented in Fig. 2.

After the first hour of incubation with the enzyme the samples of pasteurized milk (line 4) were found with clearly visible high molecular weight compounds located in the upper part of polyacrylamide gel. After 4-h incubation monomers of $\mathrm{k}$-casein practically could not be seen, while monomers of $\alpha$-casein fraction were still observed. Similar findings were reported by Huppertz and De Kruif [28] who performed SDS-PAGE examination of raw milk samples incubated with the enzyme at $30^{\circ} \mathrm{C}$ for up to $24 \mathrm{~h}$. SDS-PAGE based electrophoretic separations of the examined milk samples suggest the primary role of casein in the formation of cross-links and less pronounced involvement of whey proteins in reactions with TGM. Additionally, the least pronounced changes following the modification of the examined types of milk were found in raw milk (MS, Fig. 1) which may support the findings published by O'Sullivan et al. [5] and Rossa et al. [14] concerning the positive effects of heating on the formation of cross-links and the range of changes in the products modified with TGM.

Heating leads to irreversible changes in secondary protein structures, as a result of thermal denaturation, as well as disruption of hydrogen bonding and hydrophobic interactions giving shape to secondary, tertiary and quaternary structures of proteins, leading to altered technological and functional properties of milk and to dispersion destabilization. Additional treatments, such as concentration of dry matter ingredients with the use of ultrafiltration lead to a significant decrease in the stability of milk during heating [18].

The influence of TGM modification of proteins in raw and pasteurized milk as well as UF milk with twofold (v/v) concentration on the effectiveness of high temperature was assessed by examining heat stability at $140{ }^{\circ} \mathrm{C}$ and by determining alcohol number, defined as the quantity of $96 \%$ ethanol inducing protein coagulation in $10 \mathrm{~mL}$ of milk [27]. Ethanol induced coagulation of milk proteins is a result of dehydration of casein micelles which aggregate in the presence of calcium ions and come out of suspension in the form
Fig. 2 Electrophoretogram of cross-linked milk proteins at varied incubation time in pasteurized milk; non-modified (0) modified TGM (2)

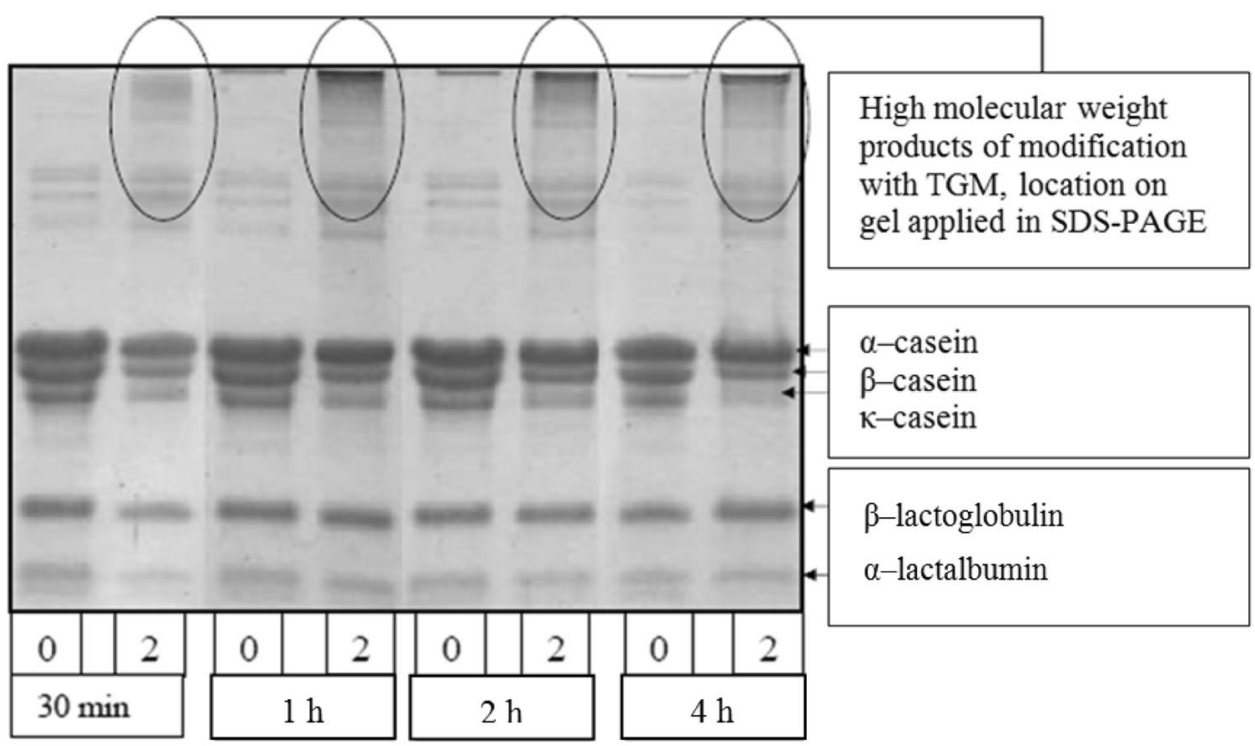


of floc. The test is a frequently applied industrial practice in the process of selecting milk for concentrates [30]. According to Kruk [29] alcohol number for thermally stable milk should not exceed the value of six.

Mean values of heat stability and alcohol number for raw milk, pasteurized milk and concentrated milk, modified with transglutaminase and for the unmodified samples are presented in Table 2. On the other hand Table 3 shows the results of analysis of variance related to the influence of the modification and type of milk on heat stability and alcohol number of the examined samples.

Modification of milk proteins with transglutaminase did not significantly impact their heat stability measured as the time of thermal coagulation. On the other hand the time of thermal coagulation at $140{ }^{\circ} \mathrm{C}$ was significantly impacted by the type of milk used in the experiment. The longest time of coagulation was found in pasteurized milk. Additionally the findings show highly significant interaction of both examined factors in relation to heat stability measured as the time of coagulation at $140{ }^{\circ} \mathrm{C}$, which according to Kruk [29] is the most reliable method of assessing this functional property of milk. Donato and Guyomarc'h [20] claim that the time of thermal coagulation in milk designated for concentrates should not be shorter than $600 \mathrm{~s}$. Taking into account this criterion, both non-modified milk and milk modified with TGM was characterized by low heat stability.

On the other hand, modification of proteins with TGM resulted in highly significant increase in the value of alcohol number, which was also significantly impacted by the type of applied milk. In the case of UF concentrate the value of alcohol number was nearly twice as high as in the raw and pasteurized milk, for which the value of alcohol number was similar. Research of ethanol stability of casein micelles cross-linked with transglutaminase was conducted by Huppertz et al. [31]. Their findings showed an increase in ethanol stability following incubation with the enzyme for $24 \mathrm{~h}$ at $30{ }^{\circ} \mathrm{C}$, by $15-20 \%$ in comparison with the non-modified samples. They also pointed to the significant effect of $\mathrm{pH}$ in the examined samples, where the increase in ethanol stability, at $\mathrm{pH} 7.5$, amounted to $80 \%$ in comparison with the samples not subjected to modification with TGM. Moreover, they demonstrated significant proportional relationship between the increasing ethanol stability and the time of incubation with the enzyme, regardless of $\mathrm{pH}$ in the examined solutions of micellar casein; this was evidenced by electrophoretic separation of proteins according to the varied
Table 3 The influence of the milk type (raw MS, pasteurized MP, concentrated milk UF) and TGM modification (non-modified sample- 0 , modified sample-2) on heat stability and alcohol number

\begin{tabular}{|c|c|c|c|c|c|}
\hline \multirow[t]{2}{*}{ Specification } & \multicolumn{3}{|c|}{ Type of milk } & \multicolumn{2}{|c|}{$\begin{array}{l}\text { TGM modi- } \\
\text { fication }\end{array}$} \\
\hline & MS & MP & UF & 0 & 2 \\
\hline Heat stability at $140{ }^{\circ} \mathrm{C}(\mathrm{s})$ & $130^{\mathrm{a}}$ & $148^{\mathrm{bc}}$ & 135 & 139 & 137 \\
\hline Alcohol number (ml) & $8.2^{\mathrm{b}}$ & $8.3^{\mathrm{d}}$ & 15.3 & 9.8 & $11.4^{\mathrm{f}}$ \\
\hline
\end{tabular}

${ }^{\mathrm{a}, \mathrm{d}}$ Significant differences between means $(\mathrm{p} \leq 0.01)$ marked with different letters in rows

incubation time. O'Sullivan et al. [5] and O'Sullivan et al. [22] in their studies focusing on the influence of transglutaminase on the heat stability of milk also emphasized the aspect of variable $\mathrm{pH}$. Experiments carried out by these authors confirmed beneficial effect of modification with TGM on the heat stability, which according to them, increases with higher $\mathrm{pH}$ of milk. They also observed a decrease in the heat stability coinciding with an increase in the concentration of the enzyme in the case of milk with normal $\mathrm{pH}$.

Han and Damodaran [32] explained that the effects of TGM on the heat stability of milk were caused by the specificity of the enzyme-substrate. In accordance with their theory, whey proteins and casein, in their normal condition, are not involved in the formation of cross-links. To facilitate cross-linking, these authors briefly heated milk at approx. $90{ }^{\circ} \mathrm{C}$ prior to its incubation with the enzyme, thus altering the structure of whey proteins and facilitating access for transglutaminase to reactive groups of amino-acid residues. Additionally, cross-links between $\beta$-lactoglobulin and $\kappa$-casein control dissociation of $\kappa$-casein from casein micelles, as a result of which they reduce the capacity for destabilization of colloidal system. Similar findings were reported by O'Sullivan et al. [5] who showed reduced dissociation of casein micelles at $\mathrm{pH}$ exceeding 6.9, as a result of which there is a linear increase in the heat stability of milk. Flanagan et al. [33] observed that addition of transglutaminase beneficially impacted the heat stability of sodium caseinate solutions at $140{ }^{\circ} \mathrm{C}$, and they also noted a positive effect of $\mathrm{pH}$ of 7.0 on the stability of modified samples of sodium caseinate.

Experiments by Lorenzen [27], designed to optimize the process of modifying milk proteins with TMG, confirmed significant increase in the heat stability of sodium caseinate
Table 2 Heat stability and alcohol number of raw milk (MS), pasteurized milk (MP) and concentrated milk (UF) for non-modified ( 0 ) and modified TGM (2) samples (mean values $\pm \mathrm{SD})$

\begin{tabular}{|c|c|c|c|c|c|c|}
\hline \multirow{2}{*}{$\begin{array}{l}\text { Type of milk } \\
\text { TGM modification }\end{array}$} & \multicolumn{2}{|l|}{ MS } & \multicolumn{2}{|l|}{ MP } & \multicolumn{2}{|l|}{ UF } \\
\hline & 0 & 2 & 0 & 2 & 0 & 2 \\
\hline Heat stability at $140{ }^{\circ} \mathrm{C}(\mathrm{s})$ & $135 \pm 4$ & $125 \pm 4$ & $132 \pm 3$ & $164 \pm 5$ & $148 \pm 8$ & $122 \pm 3$ \\
\hline Alcohol number (ml) & $7.4 \pm 0.2$ & $8.9 \pm 0.4$ & $7.5 \pm 0.3$ & $9.1 \pm 0.4$ & $14.5 \pm 0.6$ & $16.1 \pm 0.9$ \\
\hline
\end{tabular}


solution with $3.5 \%$ protein contents following modification with TGM. He also showed that by pre-heating samples of reconstituted skim milk powder with 3.5\% protein contents at $90{ }^{\circ} \mathrm{C}$ for $30 \mathrm{~s}$ it was possible to achieve cross-linking of milk proteins by transglutaminase which was $50 \%$ higher than in non-modified samples, and this in turn resulted in its improved heat stability at $120^{\circ} \mathrm{C}$. Contrary to the theory proposed by Han and Damodaran [32] with regard to the resistance of whey proteins to transglutaminase, the experiment involving 4-h-long incubation at $40{ }^{\circ} \mathrm{C}$ with an addition of TGM at the quantity of $5 \mathrm{U} \mathrm{g} \mathrm{g}^{-1}$, conducted by Lorenzen [27], showed four-fold increase in the heat stability of the solution of whey protein concentrate, at $\mathrm{pH} 6.7$ in comparison to the non-modified samples, as well as linear increase in heat stability with growing $\mathrm{pH}$.

Findings of the present study can be applied in practice; because of the short duration of the treatment and the low temperature of incubation with the enzyme the technological procedure may be adapted in processing plants without a need to modify technology lines and with no economical losses caused by prolonged duration of the process. Yet it is necessary to conduct more comprehensive research in order to explicitly determine the influence of enzymatic modification on the functionalities and physicochemical properties of milk proteins, as well as stability of nutrients and bioactivity of peptides in milk after the modification.

\section{Conclusions}

Modification by TGM leads to formation of high molecular weight compounds in the range from 55 to $194 \mathrm{kDa}$ located in the upper part of the polyacrylamide gel. Modification of milk proteins with transglutaminase did not significantly impact their heat stability measured as the time of thermal coagulation which may mean that the milk, despite being modified with warm conditions during incubation with the enzyme, retains the characteristics of fresh milk possible for further use in food processing. The time of thermal coagulation at $140{ }^{\circ} \mathrm{C}$ was significantly impacted by the type of milk used in the experiment. Modification of proteins with TGM resulted in highly significant increase in the value of alcohol number, which was also significantly impacted by the type of applied milk. This conclusion suggests a greater stability of mineral complexes in milk after enzymatic modification by TGM, according to many researchers, this feature depends on the mineral composition of milk and ionic interactions.

By confirming the beneficial impact of such modification, based on a wide spectrum of assessments, it may be possible to develop a new technological practice based on an addition of commercial transglutaminase preparation applied as a factor preserving the nutritional value and enhancing the functional properties of milk proteins.
Open Access This article is distributed under the terms of the Creative Commons Attribution 4.0 International License (http://creativeco mmons.org/licenses/by/4.0/), which permits unrestricted use, distribution, and reproduction in any medium, provided you give appropriate credit to the original author(s) and the source, provide a link to the Creative Commons license, and indicate if changes were made.

\section{References}

1. M.A. Augustin, P. Udabage, Adv. Food Nutr. Res. 53, 1-38 (2007)

2. J.L. Audic, B. Chaufer, G. Daufin, Lait 83, 417-438 (2003)

3. M. Kieliszek, A. Misiewicz, Folia Microbiol. 59, 241-250 (2014)

4. F.J. Morales, C. Romero, S. Jiménez-Pérez, Int. J. Food Sci. Technol. 35, 193-200 (2000)

5. M.M. O'Sullivan, P.C. Lorenzen, J.E. O'Connell, A.L. Kelly, E. Schlimme, P.F. Fox, J. Dairy Sci. 84, 1331-1334 (2001)

6. E.D. Omoarukhe, N. On-Nom, A.S. Grandison, M.J. Lewis, Int. J. Dairy. Techol. 63, 504-511 (2010)

7. S.G. Anema, in Milk proteins from expression to food, ed. by A. Thompson, M. Boland, H. Singh (Elsevier Inc, London, 2009), pp. 239-281

8. L. Ramasubramanian, B. D'arcy, C.D. Hilton, Int. J. Dairy Technol. 65, 183-190 (2012)

9. D.T. Davies, J.C.D. White, J. Dairy Res. 33, 67-81 (1966)

10. P. Kelly, Int. J. Dairy Technol. 59, 70-75 (2006)

11. M.S. Chavez, M.N. Livia, M.A. Taverna, A. Cuatrin, J. Dairy Res. 71, 201-206 (2004)

12. M. Czernicka, J. Domagała, M. Sady, I. Wieteska, Biotech. Anim. Husb. 25, 737-743 (2009)

13. M. Czernicka, I. Wieteska, Zesz. Nauk. AR Krak. 2, 638-644 (2009)

14. P.N. Rossa, E.M.F. De Sá, V.M. Burin, M.T. Bordignon-Luiz, LWT-Food. Sci. Technol. 44, 29-34 (2011)

15. AOAC, Official methods of analysis-dairy products. (Association of Official Analytical Chemists, Washington DC, 1995)

16. M. Jurczak, Milk, production, testing, processing (SGGW, Warszawa, 2005)

17. J.W. West, B.G. Mullinix, J.K. Bernard, J. Dairy Sci. 86, 232-242 (2003)

18. E. Kowalska, J. Pikul, P. Oziemkowski, Zywn. Nauk. Technol. Ja. 3, 78-88 (2000)

19. A. Wedholm, L.B. Larsen, H. Lindmark-Månsson, A.H. Karlsson, A. Andrén, J. Dairy Sci. 89, 3296-3305 (2006)

20. L. Donato, F. Guyomarch, Dairy Sci. Technol. 89, 3-29 (2009)

21. K. Hinz, T. Huppertz, U. Kulozik, A.L. Kelly, Int. Dairy J. 17, 289-293 (2007)

22. M.M. O'Sullivan, A.L. Kelly, P.F. Fox, J. Dairy Sci. 85, 1-7 (2002)

23. A. Pinterits, S.D. Arntfield, LWT Food Sci. Technol. 41(1), 128$138(2008)$

24. F.H.R. Abd-Rabo, S.M. El-Dieb, A.M. Abd-El-Fattah, S.S. Sakr, J. Am. Sci. 6, 612-620 (2010)

25. R. Sharma, P.C. Lorenzen, K.B. Qvist, Int. Dairy J. 10, 785-793 (2001)

26. J.H. Moon, Y.H. Hong, T. Huppertz, P.F. Fox, A.L. Kelly, Int. J. Dairy Technol. 62(1), 27-32 (2008)

27. P.C. Lorenzen, Food Res. Int. 40, 700-708 (2007)

28. T. Huppertz, C.G. De Kruif, Int. Dairy J. 17, 436-441 (2007)

29. A. Kruk, Metody oceny stabilności cieplnej mleka. Przegl. Mlecz. 8, 370-371 (2001)

30. R. Ye, F. Harte, J. Dairy Sci. 96, 799-805 (2013)

31. T. Huppertz, S. Grosman, P.F. Fox, A.L. Kelly, Int. Dairy J. 14, 125-133 (2004) 
32. X.Q. Han, S. Damodaran, J. Agric. Food Chem. 44, 1211-1217 (1996)

33. J. Flanagan, Y. Gunning, R.J. FitzGerald, Food Res. Int. 36, 267$274(2003)$

\section{Affiliations}

\section{Maria Tarapatskyy $^{1} \cdot$ Jacek Domagała $^{2} \cdot$ Grzegorz Zaguła $^{1} \cdot$ Bogdan Saletnik $^{1} \cdot$ Czesław Puchalski $^{1}$}

$\triangle$ Maria Tarapatskyy mczernicka@ur.edu.pl

$\triangle$ Bogdan Saletnik bogdan.saletnik@urz.pl

1 Department of Bioenergetics and Food Analysis, Faculty of Biology and Agriculture, University of Rzeszow, Cwiklinskiej 2D, 35-601 Rzeszow, Poland
Publisher's Note Springer Nature remains neutral with regard to jurisdictional claims in published maps and institutional affiliations.
2 Department of Animal Product Technology, Faculty of Food Technology, University of Agriculture in Krakow, Krakow, Poland 